\title{
Exclusão social e lutas por moradia na cidade de Manaus ${ }^{1}$
}

O estudo sobre as lutas por moradia na cidade de Manaus teve como objetivo analisar a trajetória histórica do Movimento dos Sem-Terra (urbano) ${ }^{2}$ - MST - nessa cidade, sua prática social na luta por moradia em relação ao processo de implementação de políticas públicas pelo poder local e o processo de construção da identidade do movimento, enquanto sujeito coletivo, frente às diferentes faces que assume no período entre 1980 a 1994.

Para a compreensão analítica destacamos as categorias movimentos sociais e políticas públicas, porém a estrutura conceituai do trabalho está ancorada na prática social dos atores que se articulam na relação Estado e sociedade, considerando especificamente os excluídos do direito à moradia, sua organização e formas de luta.

Em Manaus, as lutas coletivas desenvolvidas pelo MST (urbano) exerceram papel determinante enquanto formas de pressão contra o poder local no processo de conquista do direito à moradia.

\footnotetext{
Este trabalho trata-se originalmente da dissertação de mestrado "Movimentos Sociais e Políticas Públicas: as lutas por moradia na cidade de Manaus", apresentada ao Programa de Pós-graduação em Política Social da Universidade de Brasília, sob a orientação da Profa. Dra. Denise Bomtempo Birche de Carvalho.

2 Mestre em Política Social -UnB, Profa do Curso de Serviço Social da Universidade de Brasília

3 Movimento dos Sem-Terra foi a denominação dada ao movimento social urbano por moradia que empreendeu um amplo processo de ocupações de áreas urbanas na cidade de Manaus e teve seu início, entre 1978 e 1979, como movimento de bairro ligado à Comunidade Eclesial de Base - CEB - no bairro da Compensa. A expressão urbano aparecerá durante todo o texto entre parênteses por se tratar de uma explicitação necessária que foi incorporada ao discurso dos militantes do movimento com a eclosão das lutas do MST rural em nível nacional e especialmente no Estado do Amazonas.
} 
A este movimento atribuímos a qualidade de apresentar face nova frente às tradicionais práticas políticas dos atores sociais. As novas práticas apresentam consistência quanto ao aspecto contestador e reivindicatório nas lutas por demandas específicas e locais, buscando criar uma identidade própria e autônoma. Suas lutas expressam o processo de construção da cidadania, criando no espaço urbano a arena pública em que se manifesta a correlação de forças entres os atores sociais e se dá o exercício dos direitos sociais através da democratização do acesso à cidade.

Os processos sociais geradores da exclusão social e impulsionadores do processo da pauperização da população empurram a pobreza para áreas cada vez mais periféricas. A partir do processo de exclusão e de pauperização dessa população, é que vão se expressar as insatisfações individuais e coletivas, o que provoca o aparecimento de lutas organizadas pela conquistas dos direitos sociais negados.

Os movimentos sociais urbanos surgidos na década de oitenta contrapunham-se ao Estado, visto como um núcleo síntese do poder, estabelecendo nesta relação um visão ambígua das ações estatais. A própria necessidade de se organizarem coletivamente para enfrentar uma "esfera coletiva" do poder colocava implicitamente a percepção de que, no fundo tratava-se de uma relação de poder e não-poder (Nunes, 1991:103).

Nesta lógica empreende-se a análise da relação entre Estado e movimentos sociais, uma relação permeada de contradições que se expressa pela repressão, enfretamento, negociação, participação popular nas instâncias decisórias, alianças, cooptação política e até mesmo clientelismo. Esta relação estabelece-se em campos políticos específicos do espaço público.

A condição devida das pessoas que fazem parte dos excluídos do direito a moradia e que passam a ter na ocupação de áreas urbanas o único mecanismo de acesso à ela, relaciona-se à condição de "habitar no espaço urbano". A habitação é necessidade essencial que assegura a sobrevivência e qualidade de vida no espaço urbano tão pouco democratizado. Em nossa análise habitação é entendida como habitat, ou seja, como direito à moradia com qualidade de vida e democratização do espaço urbano, concebendo "o morar" como um fator de desenvolvimento humano e cidadania. 
A exclusão deste direito social expressa-se no cotidiano das pessoas, especificamente dos integrantes do movimento social urbano por moradia como elemento objetivador do impacto da problemática habitacional.

\section{O cenário dos conflitos}

Manaus é a capital do estado do Amazonas, por suas características político administrativas e por constituir-se em um centro de prestação de serviços, é considerada a capital regional, possuindo atualmente um contingente populacional de aproximadamente 1.246.000 habitantes em uma área de aproximadamente 14.337 km2 (Santos et alli, 1993:16).

A cidade, devido a aspectos econômicos e demográficos, é atualmente considerada a metrópole da região. Fator que influencia o aumento populacional, atraindo significativo contingente migratório que se integra à população manauense.

Entendemos que os problemas urbanos da cidade de Manaus precisam ser compreendidos a partir de aspectos sociais, políticos e econômicos. Os problemas sociais que surgem dos aglomerados humanos e dos déficit de moradia e bens e serviços públicos não podem ser atribuídos apenas ao aumento populacional, ocasionado por fluxos migratórios para a cidade; na realidade, são decorrentes de um processo que congrega exclusão social e estratégias de sobrevivência.

No período entre 1965 a 1980, a Amazônia foi aberta à expansão do capitalismo, seguindo as diretrizes de uma economia política elaborada por uma série de governos militares que pretendiam promover na região um modelo de desenvolvimento modernizante (Souza, 1994: 159). Objetivamente, este modelo de desenvolvimento autoritário visava assegurar a soberania nacional, usurpando a autoridade dos estados. Através da chamada "Operação Amazônia", 1966, definem-se as estratégias para "integrar" a região ao cenário nacional, ocupando a fronteira econômica. "Num passe de mágica , transforma-se a região numa espécie de 'fronteira' de crescimento extensivo do capitalismo, cujos centros de decisão situam-se no Centro/Sul e no Exterior." (Scherer, 1989: 34) 
Criaram-se mecanismos políticos e legislativos para o favorecimento do processo de incremento da economia, na região amazônica, que concentravam-se na capital amazonense. Manaus passou a ser o centro econômico e conseqüentemente a metrópole regional. "Pode-se depreender, a partir daí, que o ideário da Integração Nacional começa a se desenhar e concretizar-se lentamente, na medida em que esta instituição define um conjunto de medidas destinadas a intervir planejadamente na região." (Scherer, 1989:31)

Aproveitando a legislação, essas indústrias se estabeleceram numa área da cidade de Manaus, no chamando Distrito Industrial, onde receberam terrenos a preços irrisórios, totalmente urbanizados, como nenhum conjunto habitacional supostamente para pessoas de baixa renda recebeu. (Souza, 1994: 163)

A legislação consistia na atenção à demanda do capital internacional para a instalação das multinacionais em área reservada e no ordenamento legalmente exigido para as cidades em processo de desenvolvimento.

É importante observarmos dados significativos quanto à evolução populacional em Manaus para subsidiar nossa análise referente ao significativo e bombástico crescimento pelo qual a cidade passou. Em 1960 contabilizava-se 154.040 habitantes; em 1970 contabilizava-se 286.030; em 1980 observa-se um grande salto na evolução populacional urbana, contabilizando-se 626.428 habitantes (Santos et alli, 1993:20).

O significativo aumento populacional ocorreu a partir de 1967, impulsionado pela criação da Zona Franca de Manaus - ZFM -, criada com o objetivo de impulsionar o desenvolvimento da região através da criação da zona de livre comércio. Segundo Santos et alli (1993), a criação da ZFM transformou a cidade num centro absorvente e diversificado de mão-de-obra, com repercussões demográficas e econômicas significativas ao nível regional, representadas especialmente pela entrada do capital estrangeiro, a ampliação do mercado de trabalho e o incremento do setor turísticos.

Os impactos da migração no cotidiano da cidade e de seus habitantes foram extremamente significativos. Em 1980, dos habitantes de Manaus, uma terça parte era constituída de não naturais (Melo \& Moura, 1990). Ou seja, as migrações traziam como resultado um reordenamento (ou desordenamento) do espaço 
urbano, o aparecimento de novos atores sociais e a redefinição do modo de vida urbano.

Precisamos considerar que os processos migratórios para Manaus são anteriores à ZFM e, até a década de sessenta, os fluxos migratórios no sentido interior capital eram então quase que totalmente absorvidos pela "cidade flutuante" (Salazar, 1985: 46), que teve sua origem por volta dos anos vinte, após a fase áurea do extrativismo, e foi extinta nos anos 60 , como medida disciplinar para a nova ordem ${ }^{4}$. A cidade não comportava as demandas objetivas deste fluxo migratório, provocando um "inchaço" e o conseqüente aparecimento de favelas e subabitações.

Em função do crescimento populacional ocasionado pelo processo migratório, fruto do processo de implementação da ZFM e do Distrito Industrial de Manaus - DIM, expressou-se a necessidade de um planejamento que organizasse o espaço urbano na cidade. Consideramos aqui a perspectiva de análise crítica sobre os impactos sociais provocados por medidas adotadas por um planejamento econômico, tradicionalmente utilizado no Brasil que setoriza o econômico e o social.

Evidentemente que quando analisamos os fatores históricos que influenciam o crescimento populacional da cidade devemos considerar também os fatores sociais e econômicos que mobilizam estes sujeitos sociais a migrarem para cidade à procura de condições de sobrevivência, as quais vão exigir possibilidade de trabalho e moradia em primeiro plano.

Em relação especificamente à problemática da moradia, consideramos que quanto a relação entre crescimento populacional e oferta de moradia, principalmente, no que toca a população de baixa renda, as medidas governamentais podem ser historicamente consideradas esparsas, sem consistência, meramente legalistas, frágeis e, acima de tudo, clientelistas.

\footnotetext{
${ }^{4}$ A extinção da "cidade flutuante", em 1965, objetivamente tratou-se da expulsão de uma população pobre que habitava área de localização "privilegiada" próxima ao centro da cidade, em palafitas e casa flutuantes sobre o rio Negro, mesmo considerando-se as péssimas condições de sobrevivência em que se encontravam. A população da "cidade flutuante" foi retirada e lançada à própria sorte. A remoção foi um processo desenvolvido pelo governo estadual e determinado por aspectos políticos e econômicos da realidade local, evidentemente, relacionados à implantação da ZFM, que necessitava de um cenário mais adequado à nova ordem da industrialização. Contudo, a história mostrou que vários bairros surgiram das ocupações promovidas pela população oriunda dessa "cidade", um dos pontos da ocupação foi o bairro da Compensa, onde originou-se o MST (urbano).
} 
A implementação de políticas habitacionais em Manaus, para atender à população de baixa renda, aconteciam através da Companhia de Habitação do Amazonas - COHAB-AM - que tinha por finalidade suprir a moradia à população de baixa renda, com base na Política Nacional da Habitação - PNH.

Em 29.12.75, a COHAB-AM transforma-se em Sociedade de Habitação do Amazonas - ${ }^{\star} \mathrm{SHAM}^{5}$-, deixa de ser uma empresa de sociedade anônima e passa a ser estadual vinculada diretamente ao gabinete do governador, e cuja finalidade resumia-se à atenção de habitação de interesse social. A crise, o déficit habitacional brasileiro e a inoperância da $\mathrm{PNH}$, que acabou privilegiando a classe média e deixando a população de baixa renda excluída do financiamento da casa própria, refletem-se em Manaus de maneira gritante. O que provocou, a partir da década de oitenta, um processo massivo de ocupação do espaço urbano de Manaus através das chamadas "invasões".

Considerando especificamente as intervenções do poder público para a questão da moradia, notamos que os projetos com financiamento do Banco Nacional de Habitação - BNH - foram absolutamente insuficiente para atender a demanda. Dados do censo de 1980 indicavam a ampliação do setor habitacional, que passou de 52.277 domicílios, em 1970, para 114298 domicílios em 1980.

Vejamos alguns dados divulgados pela Secretaria Municipal de Assuntos Comunitários - SEMAC:

Em 1983, as populações de baixa renda (considerada de 0 a 3 salários mínimos), tinham uma demanda potencial da ordem de 122.649 habitações. Como esta faixa salarial só é atendida pelo Programa PROMORAR e de acordo com dados disponíveis do BNH, até 1983 haviam sido entregues 5.913 unidades ou lotes urbanizados, além do beneficiamento de 5.000 subabitações, fica então evidenciado um déficit na oferta de moradia para esta faixa de renda da ordem de 11.736 habitações de baixo custo (...)

Ainda... a demanda efetiva por habitação para a população que tem renda de 0 a 3 salários mínimos em 1983 é da ordem de 83.450 habitações. Levando-se em consideração que dos 39.199

\footnotetext{
${ }^{5}$ Hoje, este órgão chama-se Superintendência de Habitação do Amazonas - SUHAB.
} 
domicílios próprios de famílias de baixa renda somente 10.985 unidades foram oferecidas por programas do Banco Nacional de Habitação, isto é $28,02 \%$, infere-se que os 28.214 domicílios próprios restantes $71,98 \%$, foram adquiridos sem a utilização do Sistema Financeiro de Habitação, ou ainda, por ser habitações rústicas ou improvisadas construídas em áreas de invasão, ou seja terrenos cuja condição de posse não esteja legalizada. (Anteprojeto Reforma Urbana em Áreas de Risco, 1989: 07)

Segundo dados divulgados pelo $\mathrm{BNH}$, até 1984 os agentes financeiros financiaram um total de 24.353 unidades. Observamos que os financiamentos não atingem nem a terça parte do déficit identificado em 1983.

O início das chamadas "invasões"6 em Manaus, segundo Ramos ${ }^{7}$, datam de 30 anos atrás como um processo crescente. Este dado coincide com o período de implantação da ZFM na cidade, o que desencadeou um alto fluxo migratório. Percebendo-se que os problemas urbanos e déficit de moradia foram fatores impulsionadores do processo contínuo e massivo de ocupação da área urbana promovido pelo MST (urbano) a partir da década de oitenta.

Os problemas que se expressam no caos urbano da cidade de Manaus não se dão apenas em relação ã questão da moradia, eles se evidenciam principalmente em relação ao acesso a bens e serviços coletivos. Os processos sociais, políticos e econômicos que vêm impulsionando o "inchaço" da cidade e o caos urbano, colocamse em relação à intervenção do poder público local e as formas de expressão das demandas populares.

A trajetória do Movimento dos Sem-terra (urbano) em Manaus

6 Utilizaremos durante a análise a categoria "ocupação", por entendermos que esta 1az-se peculiar em relação a prática social do MST (urbano), tendo em vista que o poder público denomina a ocupação de terras públicas ou de latifúndios de especulação em área urbana como "invasão". Segundo Stédile e Frei Sérgio (1996: 58-60) invadir seria alguém que não precisa de terra, apossar-se de algo que pertence a outro ou a sociedade e fazer-se dono, a ocupação é legítima porque tem em vista a defesa da vida. Nesse sentido, a ocupação é legítima porque assegura a vida, ou seja, a sobrevivência dessa população que ocupa a terra exigindo cidadania e conquista de direitos sociais e melhores condições de vida no espaço urbano, com base neste argumento é que definimos a categoria ocupação a partir da visão do MST, ou seja, como conquista de direito social, direito à vida.

Dados divulgados pelo Prof. Dr. ${ }^{\circ}$ Ademir Ramos da Universidade do Amazonas em entrevista ao Jornal "A Crítica" de 23.07.97. 
tem se caracterizado como um marco diferencial no trato da questão da moradia, um processo que iniciou na década de oitenta e significou a expressão do agravamento das condições de sobrevivência na cidade, a indignação e o inconformismo diante da situação de extrema miséria e do descrédito do poder público. A carência extrema de quem não tem onde morar e nem como sobreviver frente aos problemas sociais, aliada ao compromisso de participantes da Comunidade Eclesial de Base - CEB da Igreja Católica, marcam a origem do Movimento dos Sem-terra (urbano). O movimento, na verdade, caracterizou-se como lutas pela conquista de terra para moradia em áreas devolutas ou de especulação na cidade de Manaus.

As lutas e conquistas, desenvolvidas pelo movimento social urbano, a sua relação com o poder local e com outras entidades da sociedade civil, assim como, o processo de institucionalização do movimento ocorrido a partir de 1993 com a criação da Secretaria Municipal de Organização Social e Fundiária - SEMOSF, o qual vem sendo analisado como a cooptação das lideranças, ocasionaram um fenômeno no mínimo curioso e peculiar o qual pretendemos analisar.

As políticas públicas desenvolvidas para o setor nesse período consistiam basicamente no processo de regularização de ocupações, distribuição de lotes e na desapropriação de áreas de terras particulares ou públicas para interesse social. Sem contar a atuação irrisória da SHAM, enquanto órgão responsável em atender às demandas por moradia que praticamente, passou a exercer uma participação mais política do que propriamente interventiva em relação à atenção à moradia para as pessoas de baixa renda. $O$ problema de financiamento agravou-se com a extinção do $\mathrm{BNH}$.

A prática de doação de lotes frente às necessidades da população pobre, aliada à presença no imaginário popular a relação de submissão ao poderio público, fixado na tradição imposta desde os "coronéis da borracha"8 ${ }^{8}$, vêm perpetuando e mantendo os

${ }^{8}$ Um tipo de intervenção política predominante na região se fundamenta no exercício do "mandonismo" no âmbito do poder local. A constituição deste "mandonismo" na realidade manauense tem seus fundamentos no período áureo do extrativismo da borracha (1890 à 1910). Neste, a cidade vivia sob a égide de uma economia forte e ativa, fundamentada no 
"coronéis urbanos" donos das terras. A institucionalização de um segmento mais representativo e carismático do MST (urbano) reflete uma prática de cooptação política das representações populares e a barganha dos "votos de cabresto" no período eleitoral.

\section{O progresso histórico do movimento dos sem-terra urbano em Manaus}

A trajetória do movimento é marcada pelo conhecido conflito de terras da viúva Borel, uma área ocupada pelos moradores do bairro da Compensa ${ }^{9}$ que fugiam dos altos aluguéis. $O$ confronto dos posseiros com a polícia e com a proprietária contou com o apoio da Igreja Católica e do movimento de bairro.

Os moradores do bairro da Compensa, apesar de terem a área regularizada ainda lutavam pela urbanização e pelos bens e serviços coletivos através do movimento de bairro, apoiado pela CEB, denominado Comissão Intercomunitáriade Defesa da Compensa CIDECOM. O MST (urbano) iniciou-se com a CIDECOM, que posteriormente teve o seu perfil alterado e passou a lutar pela ocupação da terra urbana.

A partir do primeiro confronto e da conquista do assentamento, os militantes deste movimento, que começava a emergir, passaram a acompanhar e promover novas ocupações, ganhando corpo e figurando de forma definitiva no cenário político da cidade.

O movimento constituiu-se, a partir do discurso dos próprios militantes, de forma espontânea, ou seja, sem muita sistematização da forma de ocupação, da organização e do enfrentamento do poder público. O movimento consolida-se tendo como liderança os membros da Igreja e da Comunidade Eclesial de Base. A princípio,

extrativismo do látex da borracha e na produção gomífera. O "coronelismo da borracha" fazia-se presente à semelhança das práticas dos grandes fazendeiros de outras regiões do país. A dominação rural representava a força política na administração pública. $\mathrm{Na}$ cidade, o poder local mantinha-se subordinado aos interesses dos seringalistas.

O nome "Compensa" surge em função de uma fábrica de compensados chamada "Compensa" que ficava próximo ao local de ocupação. A dita "invasão da Compensa" formou-se em meados de 1965, posteriormente conquistou o assentamento e virou bairro da Compensa, mostrando que o processo de ocupação urbana é anterior ao próprio movimento. 
as lideranças não seriam os próprios sem-terra mas agentes externos, um cidadão mais consciente da problemática urbana e da carência desses sujeitos, que utiliza da sua "boa vontade", dos seus conhecimentos e da capacidade de liderança e resistência para ocupar as áreas e lutar pelo assentamento.

A primeira (ocupação) foi assim, quando as pessoas entravam, foi, entravam pela necessidade, quando elas começavam a apanhar, foi que nós entramos. "Não, num pode bater não!" Imagina! Naquela época, batia mesmo. Então, aí foi que nós entramos, quando a gente conseguia a primeira... A primeira área que a gente apoiou, aí ficamos sendo um referencial. As figuras encontravam você aonde você tava. "Ó, nós tamos numa ocupação e tal." Mas geralmente sempre foi espontâneo... (M. P. - liderança do movimento).

Movidas pela carência, as pessoas agrupavam-se e conseguiam a mobilização suficiente para a ocupação de uma área, muitas vezes sem qualquer organização. Mas, a dificuldade da resistência fazia com que os posseiros fossem buscar o apoio dos agentes externos, que nessa altura já assumiam o papel de liderança. O que compreendemos como o caráter de autonomia relativa do movimento.

O início do MST (urbano), mantém uma forte influência da lgreja Católica, a maior parte de seus militantes, a princípio, eram pessoas ligadas às CEBs e que, posteriormente, passaram a integrar segmentos políticos de esquerda. Isto se expressa na própria trajetória política do movimento, que no início dos anos oitenta desenvolve sua ação de maneira dispersa, desenvolvendo uma metodologia mais simples de atuação, que depois é modificada visando à organização.

A metodologia de atuação, inicialmente, consistia em identificar a área a ser ocupada, reunir a população, estipular data para ocupação e, a partir daí, entrar no embate com o proprietário ou grileiro para a conquista da terra ocupada. Geralmente, atendendo a um mandado judicial, a polícia invadia a área, derrubava barracos e detinha os posseiros. Não havia negociação com o poder público, a relação com o poder demonstrava-se sempre de forma conflituosa, sendo a repressão a única relação que se estabelecia. Nessa altura, o movimento não tinha muita visibilidade e as formas de negociação, 
principalmente, em relação às detenções, eram resolvidas a partir da influência de membros da Igreja Católica.

A forma espontânea de ocupação empreendida pelo movimento pode ser observada pela forma de distribuição ou alocação de posseiros na área. Apesar da preocupação em manter os lotes em tamanho oficial $(10 \times 20 \mathrm{~m})$, as ruas não apresentavam um traçado definido, acontecia muita aglomeração de barracos, além de não haver preservação de áreas verdes e nem o estabelecimento de áreas para equipamentos sociais.

A participação dos agentes externos foi de fundamental importância para a organização e planejamento das novas ocupações. A metodologia que o movimento passa a desenvolver a partir das novas ocupações ocorridas, principalmente a partir de 1985, prevê novas formas de luta. Ou seja, a luta pela posterior urbanização de área já se desenvolvia a partir do assentamento. As novas ocupações passavam a demonstrar a preocupação com o traçado de ruas, áreas reservadas para a escola, o centro de saúde, o centro comunitário e para igrejas, o que expõe novas características do movimento: a organização e a articulação com entidades nacionais. Observa-se o relato de uma liderança:

...Porque certas áreas de ocupações assim aleatórias o povo não se preocupa muito em respeitar essas áreas. O que acontecia? Não havia uma liderança que fosse realmente é... vamos dizer respeitada, então depois eles solicitavam do Governo: - "Porque nós queremos escola, nós queremos isso" - "Mas, se vocês não deixaram área." Então, essa nossa preocupação era sempre em deixar espaço e entregar para o Município ou para o Governo construir uma escolas e hospitais ou seja o que for, agora não... e a gente pra conseguir isso nos tínhamos que ter uma luta ferrenha contra eles... (irmã H. W. - liderança do movimento).

A relação estabelecida entre Estado e movimento consistia na repressão, ou seja, o processo de remoção impetrado pela justiça em favor do proprietário da terra geralmente era o que prevalecia. A resistência ao despejo era, em princípio, a única arma que o movimento dispunha.

O Estado não se manifestava sobre a problemática da moradia, a repressão vinha da polícia atendendo sempre a um mandado judicial de remoção, assim como o reconhecimento da legalidade 
da ocupação também dependia de decisão judicial. Através do discurso das lideranças, é possível entender, claramente, a percepção dessa relação.

Eu me lembro que nenhum momento, nenhuma resposta que o governo nos deu foi com mesa de negociação, em nenhum momento ele nos deu isso. A única vez que nós sentamos pra negociar numa mesa foi quando nós ocupamos um colégio, (...) que o Governo não tinha pra onde correr e não iam tirar quase mil pessoas de lá também, então aí se escolheu algumas figuras, nós sentamos na prefeitura e negociamos... (M. P. - liderança do movimento)

Pelo discurso da liderança, o grande problema dos sem-terra na realidade não era o enfrentamento contra o poder local, mas contra os latifundiários e os próprios grileiros, que contavam com o apoio do governo nos seus pleitos.

O movimento desenvolvia uma luta pontual pela necessidade da moradia, única e simplesmente. Posteriormente, de forma gradativa foi conquistando mais espaço no cenário político local, o que impôs a necessidade de maior organização. A partir de 1985 e 1986, as ocupações promovidas pelo movimento passaram a exigir uma organização que assegurasse tanto as estratégias de resistência ao despejo quanto o estabelecimento de parâmetros para a ocupação que possibilitassem a futura urbanização das áreas. Era preciso pensar em termos das novas lutas e conquistas para o bairro. $O$ movimento já fazia parte da Comissão do Solo Urbano - COMSUR - que era a entidade representativa das lutas pelo solo urbano em todo o país.

A partir de meados da década de oitenta, destacando-se os anos de 86 a 88 , o movimento começou a ganhar maior visibilidade e força política na sua atuação. O apoio surge também dos partidos de esquerda como o Partido dos Trabalhadores e o Partido Comunista do Brasil. Nesse período é possível identificar um número de aproximadamente 15 pessoas que participavam como membros efetivos do movimento e começaram a definir com maior clareza o seu papel dentro do MST (urbano), pois, até então, havia uma atuação voltada para a questão da solidariedade cristã e do ideal da ajuda aos pobres desfavorecidos do que para os direitos. O discurso e a prática social se redefiniam, ou seja, surgia uma avaliação de que 
atuação destas pessoas na luta pelo solo urbano caracterizava-se efetivamente enquanto prática de liderança.

Depois de 88, 89, a gente acabou discutindo que não era. 0 nosso papel não era o de base né, seria, mais enquanto dirigente mesmo e aí a gente foi clareando já com algumas coisas mais aprofundadas né. Quando a gente começou de 87 a participar mais do movimento a nível de organização mesmo que a gente manteve contato com outros movimentos a nível nacional, aía gente começou a clarear melhor que direcionamento a gente podia darão movimento. Então, foi mais ou menos assim, né. Eu já peguei o movimento em movimento. (R. S. - liderança do movimento).

Não se falava apenas em ajudar, mas em planejar a ocupação, mobilizar a população, definir estratégias de ação, lutar pelo direito à moradia, questionar a distribuição desigual da propriedade da terra e a especulação urbana. Os membros mais ativos assumem claramente o seu papel de liderança e passam a atuar como organizadores de cada ocupação.

Essa nova face do movimento deve-se não só à influência dos partidos políticos de esquerda, mas também a uma conjuntura política e social que contribuía para o fortalecimento de movimentos dessa natureza. A preocupação de atuarjunto à população, na perspectiva de continuidade da luta, passa a ter a criação e o fortalecimento da associação de moradores como meta. A perspectiva de continuidade aparece como um desafio ao poder de cooptação do poder local, ou mesmo de políticos, que invadiam as áreas regularizadas com práticas clientelistas e com promessas de urbanização e melhorias para os bairros recém-formados.

A nova face do movimento acarretava alguns problemas quanto a sua condição, tanto em relação ao discurso como à pratica social, no cenário mais amplo. O movimento conquistou legitimidade junto à população. O número de ocupações começava a eclodir de forma incontrolável pela cidade, ocupações de toda natureza.

As lutas empreendidas pelo movimento começavam a expor a clareza em relação às conquistas de direitos. A construção da cidadania era ponto de discussão nos debates do movimento. 
Aliada à dificuldade da COMSUR em mapear todas as ocupações que vinham ocorrendo na cidade de Manaus naquele momento, as divergências internas entre alguns membros da liderança tornavam-se mais objetivas. O que antes se caracterizou apenas como diferenças de ponto de vista sobre as formas de atuação, fator que demonstra a heterogeneidade característica do movimento social urbano, naquele momento passava a representar práticas pouco conciliáveis. É importante ressaltar que as lideranças irmã H. W. e M. P., membros que militaram desde o início do movimento com uma prática articulada sobre o ponto de vista religioso, demonstram que a diferença de postura começava a se definir com a aproximação político-partidária com as esquerdas, principalmente, o Partido dos Trabalhadores. Esta postura foi parcialmente definindo a lógica da relação do movimento com o Estado, a visão das formas de negociação e, consequentemente a identidade do movimento.

Em determinados momentos é possível identificar que algumas das lideranças chegam a um certo grau de maturidade política em relação a prática relativamente ingênua e espontânea que o movimento exercia, como a perspectiva de solidariedade e opção pelos pobres.

Através da pesquisa constatamos que havia uma clara divergência interna de visão e de concepção do movimento que colocava em xeque a militância política que se aproximava dos partidos de esquerda e a prática religiosa que enfatizava a "opção preferencial solidária aos pobres". O que se expressa na fala de uma das duas lideranças entrevistadas.

Então a irmã $H$. tinha muito esse lance que é porque é pobrezinho tinha que... "Não, é porque ele é pobrezinho tinha que ter acesso a casa." Concordo, só que nós brigávamos muito porque eu dizia: "Não... mas também ele é muito pobrezinho. "Mas tem outra pessoa que também é pobre mas que está buscando, que está lutando e que tá fazendo por merecer e tá enfrentando todo um processo porque sabe que a luta não é fácil e se você age dessa maneira você simplesmente tá usando de paternalismo, que não é a nossa proposta. Depois de muito tempo a gente acabou terminando... rachamos, né. Lá a irmã $H$. foi pra um lado, a gente foi pra outro, 
então foi desastrosa a história. (M. P.- liderança do movimento).

A cisão do movimento em dois grupos que lutavam pelos mesmos objetivos, com enfoques e visões diferenciadas de corno desenvolver a luta, deu início ao processo que resultou posteriormente na institucionalização de um desses grupos. $O$ episódio da cisão aconteceu por volta de 1987, quando ocorreu a discordância da forma ocupação de uma área que estava sendo controlada por grileiros que dispunham de capangas armados com ordem para matar os posseiros. Esta área foi legalizada através de uma acordo entre o Governador Amazonino Mendes e irmã. H. W. (liderança do movimento), a discordância em torno dessa aliança foi o elemento cabal da cisão.

A irmã H. W. como liderança carismática, passou a situar-se de forma mais evidente no cenário político local, pela ousadia e destemor com que enfrentava as reações e as pressões ao movimento. No entanto, o enfoque político com que trabalhava era bastante complicado e de certa forma ingênuo.

A perspectiva da participação de representantes políticos no movimento é percebida a partir do compromisso em ajudar o povo. A idéia mais ampla de conquistas de direitos sociais fica esvaziada, dando lugar à caridade e ao imediatismo no atendimento às demandas. O discurso revela uma preocupação que condiz com o caráter muito mais imediatista da questão, ou seja, dar terra a quem precisa. A conotação deixa uma lacuna para os paliativos e para 0 clientelismo.

É importante considerar a conjuntura política nacional que, naquela época, colocava em pauta o processo de democratização e a participação popular no cenário político mais amplo como condição de democracia. A proliferação das ocupações naquele período e a nova situação de legitimidade do movimento frente ao Estado, em função do discurso da participação política no processo decisório, por um lado, mostravam a força do movimento por moradia e, por outro, dispersavam suas lideranças. Além disso surgiam pequenos especuladores no interior do movimento disseminando aspecto negativo frente à opinião pública. Apesar do movimento sempre contar com o apoio da imprensa nas ocupações, a pressão dos grandes especuladores imobiliários e dos grileiros era grande no 
centido de ressaltar a ocupação de lotes por pessoas que não precisavam.

O processo de institucionalização do movimento começava a se definir anteriormente a 1993, antes da criação da secretaria (SEMOSF). Cabe ressaltar, que esta institucionalização acontece especificamente com o grupo liderado pela irmã $\mathrm{H}$. W. e não com o movimento com um todo. Este grupo passou, a partir da ocupação do Armando Mendes, a manter uma nova postura de negociação com o governo, assim como, uma ação do poder local parecia buscar alianças com o movimento.

\section{Relação movimento dos sem-terra urabano e poder local: da repressão à legitimidade}

Para melhor estruturação da análise sobre a relação entre o Movimento dos Sem-terra (urbano) e o poder local na cidade de Manaus achamos prudente organizar os temas repressão, legitimidade e alianças como norteadores da trajetória histórica em que definem este tipo de relação. No bojo da análise destacaremos a constituição da identidade coletiva do movimento.

Evidentemente que não se pode compreender este processo como momentos claramente definidos, tentaremos identificar apenas metodologicamente as tendências de cada momento histórico, organizando cronologicamente as diferentes faces que assume 0 movimento e a relação estabelecida com o poder local.

Analisaremos três períodos específicos:

\subsection{Período entre 1980 e aproximadamente 1984}

Este período caracterizou-se pela fase inicial do movimento, o momento de sua estruturação, quando este deixa as lutas isoladas em busca de organização. O movimento iniciado com a CIDECOM passou a definir-se como entidade representativa a partir de sua articulação com as CEBs. A identidade coletiva do movimento começava a formar-se com grande influência dos setores progressistas da Igreja Católica, ou melhor, o sujeito coletivo formavase a partir da carência e da solidariedade cristã. 
"O movimento surgiu como surge como quase todos os movimentos, sem pé e sem cabeça, sem projeto, sem pensar em nada, ele começou de uma maneira quase aleatória..." (S. M. militante do movimento)

A ocupação do bairro da Compensa era uma referência de conquista da terra feita pela CIDECOM. A partir daí, grupos aleatoriamente organizavam-se para ocupar uma determinada área e solicitavam o apoio das lideranças dessa comissão. Com a presença dos agentes externos ligados à Igreja, o movimento começou a pensar-se como sujeito. O processo de planejamento das ocupações e das estratégias de permanência construíam-se pela experiência, a luta era pautada na necessidade e no enfrentamento. O processo organizativo, propriamente dito, surge a partir da interface com outras entidades, como partidos políticos de esquerda e sindicatos.

Eu participei apenas de uma ocupação de terra que foi planejada por nós, o resto, as outras surgiu e nós íamos lá com a experiência quejá tínhamos dá um apoio pro pessoal, no sentido de organizar. Então, depois três, dois, três anos, nós começamos a nos reunir sistematicamente para discutir a questão do movimento em si. As pessoas principalmente que estavam engajadas nesta questão. $E$ começamos a discutir, por exemplo, quando havia o movimento a gente sempre esbarrava na questão política, nas leis, isso era o nosso maior entrave. Então isso nos levou a nos organizarmos. (S. M. - liderança do movimento)

Registra-se pouca intervenção da administração pública, tanto da prefeitura como do governo do estado, em relação à problemática da moradia. A omissão da administração pública em nível de políticas e a repressão ao movimento eram predominantes nesse período, mesmo no caso dos administradores mais demagógicos.

No início quando o Amazonino foi prefeito pela primeira vez, nós estávamos começando, nós já estávamos num processo durante uns dois anos de organização, mas aíquando o Amazonino vem, foi quando surgiu a primeira ocupação. No início o relacionamento foi bom, porque ele tava ainda fazendo média, aquela coisa de dizer que ele era o maravilhoso e tal. E saiu pras comunidades e a gente acompanhou aquela coisa toda, mas quando você dizia o que queria, 
o Governo recuava. Então a nossa relação com ele, não havia nenhuma relação movimento e governo, as únicas relações que se deram eram relação de enfrentamento mesmo, né. Então não havia nenhuma negociação ou coisa parecida, a não ser já quando a irmã $H$. já conversa com o Amazonino, mas eles não nos recebiam, né... (M. P. - liderança do movimento)

A intervenção em relação às ocupações só acontecia mediante fato consumado, quando a repressão não resolvia, com 0 assentamento ou a remoção. A urbanização nas áreas de ocupação só era conquistada a partir de muita luta dos movimentos de bairro.

Durante a fase inicial do movimento por moradia, algumas áreas foram conquistadas à custa de muita luta e resistência, como no bairro da Paz, em 1983; e outras áreas foram perdidas, como a ocupação do Aiapuá, por exemplo, que foi altamente reprimida pelo Estado por se tratar de um área nobre.

A construção da identidade coletiva do movimento definia-se, também, a partir da afirmação da autonomia em relação ao Estado, apesar da autonomia relativa em relação à presença do agente externo, no caso, a Igreja Católica. Ainda não havia a clara consciência da sua capacidade interventiva na realidade, na conquista e democratização do espaço urbano. Porém o movimento apresentava uma postura crítica, em relação ao Estado, que se fundamentava principalmente no descrédito com o poder público.

\subsection{Período entre 1985 e aproximadamente 1989}

Esse período caracterizou-se por uma maior legitimidade política do movimento e não obstante marcou sua cisão.

A política de repressão era mantida e as áreas eram conquistadas com árduas lutas. Contudo, novos aspectos apresentavam-se no cenário de luta que acabaram por inferir na movimentação dos atores. O processo de redemocratização nacional, eleições diretas e efervescência de movimentos sociais urbanos, que exigiam maior participação popular na gestão de políticas públicas, eram fatores que impulsionavam a articulação das lutas localizadas com entidades de representação nacional. O MST articulou-se com a COMSUR e passou a redefinir suas estratégias 
de intervenção. Novas práticas foram se evidenciando tanto em relação ao movimento quanto em relação ao Estado.

A força social do movimento se evidenciava, este começou a atingir legitimidade pública e reconhecimento da sua luta. O apoio de outras entidades da sociedade civil foi fundamental para o fortalecimento do movimento. A identidade do movimento passou a se definir a partir da perspectiva de demandas e direitos, contando com apoio de entidades representativas no processo de formação da consciência coletiva.

A problemática urbana e a gestão do espaço urbano estavam em pauta. O MST (urbano) passou a ter reconhecimento público frente à sociedade manauense. A repressão às ocupações passaram a ser intensamente divulgadas pela imprensa local e recebiam a solidariedade de várias entidades, através, por exemplo, de moções públicas.

O movimento partia em busca do apoio dos mais diferentes segmentos representativos da sociedade civil, como os partidos políticos de esquerda e o Sindicato dos Metalúrgicos, que já tinha uma certa experiência de luta e dispunha de uma infraestrutura de suporte para as manifestações. Os militantes começaram a repensar o seu papel político dentro do movimento agora enquanto liderança.

"... pelo fato das pessoas que ocupam a terra, na época era assim, são pessoas que não tinham, que não tinham um mínimo de conhecimento, a gente na prática acabava se tomando uma espécie de dirigente, porém deixando bastante autonomia para eles. Como nós tínhamos uma visão maior, um conhecimento maior, uma experiência maior, nós atuávamos como, prestando assessoria, informações..."(S. M.- liderança do movimento)

A COMSUR, pela tomada de consciência das lideranças, passava a se definir enquanto órgão representativo das lutas por moradia na cidade, detinham um controle sobre todas as áreas que estavam sendo ocupadas e seus membros trabalhavam na organização da ocupação e nas estratégias de resistência ao despejo.

A intervenção do poder público na questão da moradia acontecia predominantemente no âmbito do governo do estado. Todavia, quanto à problemática específica das ocupações, havia contradições nos discursos das competências entre a URBAM e a 
SHAM. Conforme nota da imprensa local, o superintendente da Sociedade de Habitação do Amazonas - SHAM atribuía aos governos estaduais anteriores a 1986 a responsabilidade pelo déficit de 100 mil moradias em Manaus; entretanto, o diretor-presidente da Empresa Municipal de Urbanização do Amazonas - URBAM afirmava que a desapropriação de terrenos do estado para a distribuição à população carente dependia do $\mathrm{BNH}$.

A Fundação de Desenvolvimento e Ação Comunitária FUNDAC passou a interferir nas ocupações, cadastrando os moradores para a distribuição de lotes. As políticas voltadas para moradia popular, especialmente até 1988, consistiam-se basicamente na desapropriação de áreas para interesse social e na concessão de lotes.

Evidentemente que a entrada de agentes do poder público nas áreas ocupadas, prometendo terra, significava um claro interesse de "cooptação", visto que, no imaginário popular, o representante do poder apresentava-se como o benfeitor concedendo a moradia. Essa prática caracterizava-se para o movimento como um desafio, maior que a própria repressão, pois sua força política e a legitimidade significavam o questionamento às estruturas políticas e ao mesmo tempo poderiam despertar interesses político-eleitoreiros.

Havia certa dificuldade, tanto da base como de lideranças do movimento em compreender esse processo de legitimação política como uma conquista advinda da força social do MST (urbano). A base ficava fragilizada e vulnerável à "cooptação" clientelísta, promovida especialmente pelo governo do estado. Por outro lado, as divergências internas entre as lideranças tornavam-se evidente, desencadeando o processo de cisão.

"...os movimentos tendem a apresentar uma dupla face: a pública, que enfatiza a igualdade, a união, o consenso; e a oculta, das cisões, divergências, acusações mútuas, discriminações que só são reconhecidas para serem deploradas, mas que contribuem muito para o sabor, a intensidade e a dramaticidade dessa prática coletiva. "(Durham, 1984: 30)

A busca da construção da nova identidade, o sujeito que quer fazer-se transformador, a organização, a articulação nacional conviviam com os impasses internos, característicos da 
heterogeneídade do movimento, e contavam com a interferência do poder público. A autonomia relativa conquistada em relação aos partidos e à Igreja mantinha-se e legitimava-se na nova conjuntura das lutas. Porém a autonomia total em relação ao Estado estava ameaçada.

A cisão do movimento efetivou-se basicamente em dois grupos, um que mantinha clara posição de embate ao poder público e outro, que partiu para as alianças, edificado basicamente no carisma da irmã H. W.

"Sim, porque a gente passou a trabalhar organizadamente essa coisa toda. E a irmã $H$. começou a participar da COMSUR. Só que com a saída da irmã $H$. do nosso grupo, ela também se afastou da articulação nacional. Então ela passou a viver e a planejar só a partir da visão dela local ali." (M. P. - liderança do movimento).

Em seguida, aconteceu um processo de personificação do movimento e esse passou a ser reconhecido a partir da liderança carismática, obscurecendo a atuação da COMSUR. A liderança fazse presente nas representações dos atores como o líder impoluto, carismático, que exerce um poder/saber originado das massas e tem uma influência muito forte sobre o imaginário popular, usando por muitas vezes uma postura autoritária para fazer valer suas opiniões.

"O movimento pelo solo urbano aqui em Manaus foi personalizado pela irmã $H$. que nunca quis sentar com os movimentos, em particular o CIMI e a CPT, aos quais ela tava pedindo ajuda, mas ela nunca quis sentar para discutir avaliações políticas e as opções que ela estava fazendo..."(H. G. - membro da Igreja)

O descrédito no poder governamental ratifica o aparecimento da liderança popular que está presente no cotidiano e conduz as massas. "Seja a partir de organizações voltadas para a gestão de carências cotidianas ou de natureza mais ampla, os movimentos sociais carregam em suas práticas dimensões simbólicas importantes a serem analisadas." (Barreira, 1993: 169).

\subsection{Período entre 1989 e 1994}

Período marcado pelo processo de alianças entre o poder local e o MST (urbano). 
A COMSUR transformou-se em articulação e passou a se denominar Associação Nacional do Solo Urbano - ANSUR. O segmento do movimento que manteve-se ligado a ANSUR articulouse a outras lutas no cenário urbano, como as organizações de bairro e mostrou-se um ator extremamente atuante na discussão do plano diretor. No entanto, perdeu o controle sobre o número de ocupações que passaram a ocorrer na cidade, motivadas, por um lado, pela legitimidade política do movimento e, por outro, pelas práticas clientelistas de concessão de lotes.

Este fator provocou o aparecimento de novas segmentações e disseminação de novas lideranças, menos expressivas, que mantinham as mesmas estratégias de ocupação do MST (urbano). Novos atores entraram em cena e criaram várias formas de lutas que misturam carência, especulação e clientelismo.

A partir de 1989, este quadro político começa a redefinir-se com a eleição de Arthur Neto para a prefeitura municipal, que no início do mandato foi amplamente apoiado por partidos políticos de esquerda. A nova postura política do poder local estabelecia novas práticas entre os atores.

Essa administração foi a única que sinalizou com uma proposta de reforma urbana. A atuação consistiu especialmente no atendimento aos flagelados da grande enchente de 1989, com a remoção de moradores de áreas de risco para um novo bairro, totalmente planejado (bairro Jorge Teixeira). O diálogo buscado entre prefeitura e representações da sociedade civil foi extremamente positivo, com abertura à participação popular.

"É, a irmã $H$. pra nós... a mudança dela foi uma grande derrota pra nós por conta das mudanças né que aí ela fortaleceu, se tornou um braço do governo contra nós, né conhecia tudo que a gente era capaz de fazer. E aí foi na época que o Amazonino assumiu o governo, o Artur Neves também. O Artur a gente conseguiu trabalhar uma época junto apesar de muitas coisas, ele deu muitas aberturas no governo de reivindicar, de receber. Com o Amazonino não; o trabalho dele sempre foi de cooptação mesmo. É uma diferença....há uma diferença entre os dois. "(R. S. - liderança do movimento)

O segmento do movimento ligado a ANSUR entrava em refluxo, 
no entanto, o MST (urbano) liderado pela irmã H. W. continuou atuando em busca de alianças.

"... nós decidimos que a parte de lá nós só iríamos fazer um acompanhamento mais teórico. A gente não ia ficar mais nesse negócio de ocupar, ocupar porque a gente, porque o movimento também tava entrando num certo refluxo naquela época,..."(R. S. liderança do movimento)

As propostas de reforma urbana precisavam ultrapassar a dimensão de aspectos apenas urbanísticos ou apenas sociais. $O$ planejamento de uma bairro e a distribuição de lotes a populações carentes não interferem de maneira significativa para a superação da problemática da moradia. A administração pública, por vezes, torna-se refém da vontade popular, quando esta expressa a sua força social, visto que, as práticas clientelistas geram a dependência e o ciclo vicioso.

O número de ocupações era crescente e em muitas delas existia a presença do pequeno especulador, que ocupava e vendia lotes, após ou durante a regularização. A impossibilidade do poder público administrar essa problemática manteve-se pelo persistente hiato entre o econômico e o social, desenvolvido nas políticas públicas.

O segmento do movimento que buscou a institucionalização das lutas, através das alianças do poder governamental, acreditou que as conquistas seriam legitimadas e a solução da problemática da moradia tornar-se-ia possível somente por essa via.

Por outro lado, a cooptação da principal liderança do movimento talvez tenha mascarado a real intenção de "dominar as regras do jogo", ou seja, o exercício do poder pela própria liderança do movimento. Obtendo um controle sobre a propriedade da terra, detendo os mecanismo do Estado, seria mais fácil a concessão de lotes e, por outro lado, possibilitaria a posse definitiva. Além disso, seria possível manter um controle sobre os focos de ocupação e coibir especuladores e grileiros, utilizando-se do carisma e do reconhecimento público frente aos setores populares.

A vontade de exercer um tipo de "mediação", que levasse a demanda popular para as instâncias do poder, diferenciando-se da "mediação" a que se refere Scherer-Warren (1996: 63). Aquela que 
deveria ser exercida na articulação entre movimentos e partidos políticos, especialmente os de esquerda, em direção à uma hegemonia cultural, significando um novo equilíbrio entre sociedade civil e Estado, fortalecendo a primeira e diminuindo o poder relativo do segundo.

A princípio, esta estratégia seria viável, porém "ingênua" quando constata-se que a concessão de lotes não soluciona o problema. A institucionalização de um segmento do movimento em secretaria municipal transforma-o em administração pública, as lideranças perdem as referências e o diálogo com os outros diferentes segmentos do movimento deixa de existir. As ocupações continuaram ocorrendo e sendo reprimidas. O órgão público passou a servir a interesses político-eleitoreiros, com referendo das práticas clientelistas, como trataremos a seguir.

A nova face do movimento define-se pela dependência ou a partir das alianças políticas. As respostas do Estado às demandas populares situam-se sempre em um terreno de ambigüidades. A interação de ingerências políticas, da cooptaçao e do clientelismo aparece como a verdadeira regrado jogo, desvirtuando as propostas originais do movimento (Jacobi, 1983:176-77).

Contando-se com o processo ocorrido em nível nacional, que trouxe para o campo da administração pública o viés da participação popular nos processos decisórios e que colocou no poder partidos de esquerda ou alianças democráticas, o impacto desse fenômeno, de certa forma, não foi absorvido na política amazonense, que continuou mantendo no poder os velhos "coronéis" ou as práticas tradicionais travestidas de um discurso de luta pelos interesses do povo. Do discurso à prática, os interesses hegemônicos prevalecem, mesmo considerando-se os mecanismo de pressão popular.

A incorporação do movimento na estrutura do poder público local, mais do que um processo de cooptaçao, resultou numa inversão do campo político da luta que esbarrou no antagonismo e no confronto com posições hegemônicas, ou seja, o jogo de interesses. Este, perpetuou-se no campo político, foi um empecilho para que os ideais do movimento se materializassem através das políticas públicas, assim como, a incorporação das lutas populares 
pelo poder público eram fictícias e improváveis. As divergências políticas evidenciaram-se em meio às alianças.

A institucionalização do movimento social em secretaria e a continuidade das ocupações promovidas pelas dissidências revelam mais do que a face oculta do movimento e o mero conflito interno entre os atores que o compõem.

O movimento social por moradia em Manaus estruturou sua luta. Partiu da perspectiva de carência e solidariedade para a de lutas por direitos e cidadania, desenvolvida a partir da interface com as entidades da sociedade civil e com partidos de esquerda. Contudo, a questão da cidadania coloca-se em xeque com o processo de institucionalização e com a inversão da perspectiva de luta por direitos.

\section{Considerações finais}

Estudar o movimento por moradia implicou em perceber as diferenças, a heterogeneidade e os conflitos que se fazem presente na sua face oculta. O propósito de compreender a identidade dos sujeitos urbanos implica desconstrução e reconstrução do fenômeno, um processo extremamente complexo e que está à mercê de inferências e de interpretações pré-concebidas.

A primeira constatação a que chegamos diz respeito à constituição da identidade do MST (urbano). Esta constituiu-se a partir das representações que envolvem a cultura, a ideologia, a subjetividade, o cotidiano e as relações de classe dos sujeitos sociais que compõem o movimento. A identidade, que congrega carências comuns e projeto coletivo, constitui-se a partir das diferentes formas de enfrentamento ao poder público. Estas formas de enfrentamento são a força motriz das lutas por moradia, na busca de legitimidade e de reconhecimento como sujeito coletivo. A identidade do MST (urbano) em Manaus pequenos especuladores expressa-se e manifesta-se de diferente formas, estabelecendo divergentes práticas sociais exercidas em relação ao poder local, no decorrer do período aqui considerado, a saber: 
a) A princípio, como forma de resistência à repressão com lutas de caráter radical e de oposição ao poder instituído;

b) Posteriormente, o enfrentamento em busca de negociação e de reconhecimento da legitimidade, tanto em relação ao poder público quanto em relação à sociedade;

C E finalmente, a desarticulação interna que divide o movimento em um segmento oposicionista ao poder político instituído, porém atravessando um processo de refluxo; e em outro segmento que parte para as alianças através do pacto político com o poder local se institucionalizando.

O movimento assume diferentes faces que se evidenciam na relação com o Estado durante a sua trajetória. Classificamos como quatro faces: 1) rebeldia/repressão; 2) organização / reconhecimento de legitimidade; 3) cisão/novo direcionamento político; 4) institucionalização/clientelismo.

A segunda constatação diz respeito à ação do poder público local que no processo de regularização de áreas ocupadas ou com a remoção e assentamento em outras áreas e demais práticas políticas com relação à questão da moradia, só se realizaram em Manaus pelas pressões políticas dos setores populares organizados, especialmente o MST (urbano). As políticas públicas vêm sendo implementadas a reboque das iniciativas populares e, por diversas vezes, apropriando-se de suas bandeiras de luta. Imprime, portanto, um caráter funcional às práticas sociais do movimento em relação a execução dessas políticas.

As políticas públicas para o setor da moradia das populações pobres em Manaus tem se fundamentado nas tradicionais práticas clientelistas. A funcionalidade do movimento em relação a intervenção do poder público entra em confronto com a idéia do contrapoder que viria das massas. A relação Estado sociedade estabelece-se a partir das contradições sociais e da correlação de forças que manifestam-se de formas diferenciadas em cada realidade específica. 


\section{Bibliografia}

BARREIRA, I. A. F. "Entre rebeldia e disciplina: dimensões simbólicas e políticas nos movimentos sociais urbanos". In: Irlys A. F. Barreira \& Elimar Pinheiro do Nascimento. Brasil Urbano: cenários da ordem e da desordem. Rio de Janeiro: Notya; Fortaleza-CE, SUDENE, Universidade Federal do Ceará, 1993. pp. 165-175.

DIAS, Einéia Mascarenhas. A Ilusão do Fausto. Dissertação de Mestrado. São Paulo: PUC, 1988.

DURHAM, E. R."Movimentos Sociais: a construção da cidadania". In: Novos Estudos CEBRAP. São Paulo n. ${ }^{\mathrm{Q}}$ 10, nov/1984. pp. 24-30.

FREI SÉRGIO \& Stédile, J. P. A Luta pela Terra. São Paulo: SCRITTA, 1996.

GONÇALVES, M. da O V. Favelas Teimosas: luta por moradia. Brasília, década de 80. Tese de Doutorado, São Paulo, PUC, 1995.

JACOBI, P. "Movimentos Populares Urbanos e Respostas do Estado: Autonomia e controle vs, Cooptação e Clientelismo". In: Renato Raul Boschi (org.). Movimentos Coletivos no Brasil Urbano. Rio de Janeiro: Zahar, 1983. pp. 145-179.

MELO, M. L. de \& MOURA, H. A. de (coord.) Migrações para Manaus. Recife: FUNDAS, Ed. Massangana, 1990.

NUNES, B. F. "Revisitando Aspectos da Questão Urbana'. In: Revista Sociedade e Estado, Vol. VI, n. ${ }^{9} 2$, jul-dez/1991, p.99-114.

SALAZAR, J. P. O Abrigo dos Deserdados (Estudo sobre a remoção dos moradores da Cidade Flutuante e os reflexos da Zona Franca na habitação da população de Baixa Renda. Dissertação de Mestrado. São Paulo: USP, 1985.

SANTOS, S. S. Moreira dos (coord.) Saneamento Básico e Problemas Ambientais no Município de Manaus. In: Revista Brasileira de Geografia e Estatística. Rio de Janeiro: IBGE, V.55, n. 114, Jan/dez, 1993. pp. 1-216.

SCHERER, E. F. Assistência aos Desassistidos Manauaras. Dissertação de Mestrado. São Paulo, PUC, 1989.

SCHERER-WARREN, Redes de Movimentos Sociais. São Paulo: Loyola 1996.

SOUZA, M. Breve História da Amazônia. São Paulo: Marco Zero, 1994.

TOMMASI, L. de. Em Busca da ldentidade: As lutas em defesa dos direitos da criança e do adolescente no Brasil e a questão da participação. Tese de Doutorado. Universidade de Paris I. Paris, 1997. Mimeo. 